Disclosure of Interest: None declared

DOI: 10.1136/annrheumdis-2018-eular.1688

\section{FRI0203 THE LINK BETWEEN COPD AND ANKYLOSING SPONDYLITIS: A POPULATION BASED STUDY}

K. Sharif ${ }^{1}$, A. Watad ${ }^{2}$, S. Tiosano ${ }^{2}$, Y. Yavne ${ }^{2}$, D. Comanehster ${ }^{3}$, A. Cohen ${ }^{4}$ H. Amital ${ }^{2}$. ${ }^{1}$ Sheba medical centre, Tel aviv, ${ }^{2}$ Sheba Medical Centre; ${ }^{3}$ Clalit, ${ }^{4} \mathrm{CLalit}$ health services, Ramat Gan, Israel

Background: Ankylosing spondylitis (AS) is one of the most common and severe subtypes of the spondyloarthropathies. Extra-articular involvement among AS patients, including lung disease, has been described widely. Chronic obstructive pulmonary disease (COPD) has been linked to several autoimmune diseases, however, very few studies have investigated the association between AS and COPD.

Objectives: To assess whether an association exists between AS and COPD.

Methods: A population-based cross-sectional study was conducted using data retrieved from the largest electronic medical records database in Israel, the Clalit Health Services (CHS). Patients were defined as having AS or COPD when there was at least one such documented diagnosis in their medical records. The proportion of COPD was compared between AS patients and controls. A logistic regression model was used to estimate the association between AS and COPD in a multivariate analysis adjusted for age, gender and smoking status

Results: The study included 4076 patients with AS and 20290 age- and sex-frequency matched controls. The proportion of COPD in AS patients was higher than in controls $(46 \%$ vs. $18 \%$, respectively, $\mathrm{p}<0.001)$. Multivariate logistic regression demonstrated a robust independent association between AS and COPD (OR 1.225, $\mathrm{p}=0.031$ ).

Abstract FRI0203 - Table 1. Interactions between COPD, covariates by strata and AS

\begin{tabular}{|c|c|c|c|c|c|}
\hline & $\begin{array}{c}\text { ALL } \\
\mathbf{n}=24366\end{array}$ & $\begin{array}{l}\text { Controls } \\
n=20290\end{array}$ & AS $n=4076$ & OR & $\mathbf{P}$ \\
\hline COPD & $628(2.58 \%)$ & 431 (2.12\%) & $\begin{array}{c}197 \\
(4.83 \%)\end{array}$ & $\begin{array}{c}2.34 \\
{[1.97 ; 2.78]}\end{array}$ & $<0.001$ \\
\hline $\begin{array}{l}\text { Gender: } \\
\text { Female }\end{array}$ & 172 (1.95\%) & $117(1.60 \%)$ & 55 (3.74\%) & $\begin{array}{c}2.40 \\
{[1.72 ; 3.30]}\end{array}$ & $<0.001$ \\
\hline Gender: Male & $456(2.93 \%)$ & $314(2.42 \%)$ & $\begin{array}{c}142 \\
(5.45 \%)\end{array}$ & $\begin{array}{c}2.32 \\
{[1.89 ; 2.84]}\end{array}$ & $<0.001$ \\
\hline Age: $18-44$ & $14(0.19 \%)$ & $8(0.13 \%)$ & $6(0.50 \%)$ & $\begin{array}{c}3.94 \\
{[1.27 ; 11.6]}\end{array}$ & 0.020 \\
\hline Age: 45-69 & 306 (2.42\%) & $189(1.78 \%)$ & $\begin{array}{c}117 \\
(5.70 \%)\end{array}$ & $\begin{array}{c}3.34 \\
{[2.63 ; 4.22]}\end{array}$ & $<0.001$ \\
\hline Age: $70_{+}$ & 308 (7.25\%) & $234(6.83 \%)$ & $74(9.01 \%)$ & $\begin{array}{c}1.35 \\
{[1.02 ; 1.77]}\end{array}$ & 0.034 \\
\hline SES: Low & 268 (5.35\%) & 193 (5.47\%) & 75 (5.04\%) & $\begin{array}{c}0.92 \\
{[0.69 ; 1.20]}\end{array}$ & 0.542 \\
\hline SES: Medium & $247(4.72 \%)$ & $154(4.36 \%)$ & 93 (5.47\%) & $\begin{array}{c}1.27 \\
{[0.97 ; 1.65]}\end{array}$ & 0.077 \\
\hline SES: High & 97 (3.46\%) & 68 (3.54\%) & $29(3.27 \%)$ & $\begin{array}{c}0.93 \\
{[0.59 ; 1.43]}\end{array}$ & 0.729 \\
\hline $\mathrm{BMI} \leq 25$ & $172(4.11 \%)$ & $111(3.86 \%)$ & 61 (4.64\%) & $\begin{array}{c}1.21 \\
{[0.88 ; 1.66]}\end{array}$ & 0.242 \\
\hline $\mathrm{BMI}>25$ & $338(4.49 \%)$ & $204(4.20 \%)$ & $\begin{array}{c}134 \\
(5.04 \%)\end{array}$ & $\begin{array}{c}1.21 \\
{[0.97 ; 1.51]}\end{array}$ & 0.094 \\
\hline Smoking & $454(8.23 \%)$ & 304 (8.34\%) & $\begin{array}{c}150 \\
(8.01 \%)\end{array}$ & $\begin{array}{c}0.96 \\
{[0.78 ; 1.17]}\end{array}$ & 0.674 \\
\hline
\end{tabular}

$\mathrm{N}$ : number of cases; AS: ankylosing spondylitis; BMI: body mass index $\left(\mathrm{kg} / \mathrm{m}^{2}\right)$; SES: socioeconomic class; COPD: chronic obstructive pulmonary disease.

Note: The table presents stratified analysis of COPD patients. Reference category for each stratum is patients without COPD.

Abstract FRI0203 - Table 2. Logistic regression - Covariates associated with COPD

\begin{tabular}{lccc}
\hline Variable & OR & $\mathbf{C l}$ & $\mathbf{p}$ \\
\hline Age (years) & 1.078 & 1.0711 .085 & $<0.001$ \\
Gender: & 1.042 & 0.8631 .263 & .671 \\
Male & & & \\
Smoking & 9.862 & 8.174 & $<0.001$ \\
AS & 1.225 & 11.949 & .031 \\
\hline
\end{tabular}

OR: odds ratio; $\mathrm{Cl}$ : confidence interval; AS: ankylosing spondylitis; COPD: chronic obstructive pulmonary disease.

Conclusions: Our study supports an association between AS and COPD, further extending the link between COPD and autoimmune diseases. This finding highlights the importance of smoking cessation in AS patients and raises the question of whether COPD screening may be warranted.

Disclosure of Interest: None declared

DOI: 10.1136/annrheumdis-2018-eular.3917

\section{FRI0204 RADIOGRAPHIC PROGRESSION OF} SPONDYLOARTRITIS PATIENTS AFTER 13 YEARS OF FOLLOW UP: DATA FROM THE REGISPONSER DATABASE

L. Pérez Sánchez ${ }^{1,2,3}$, P. Font ${ }^{1,2,3}$, C. López ${ }^{1,2,3}$, L. Bautista ${ }^{1,2,3}$, L. Ladehesa ${ }^{1,2,3}$ I. Gómez ${ }^{1,2,3}$, A. Escudero ${ }^{1,2,3}$, E. Collantes ${ }^{1,2,3}$, M.C. Castro ${ }^{1,2,3} .{ }^{1}$ Reina Sofia University Hospital; ${ }^{2}$ IMIBIC, ${ }^{3}$ University of Cordoba, Cordoba, Spain

Objectives: To describe the radiographic evolution after 13 years of follow-up in a monographic consultation of patients with Axial Spondyloarthritis (EspAax) included in REGISPONSER at the Reina Sofía University Hospital in Córdoba.

Methods: Seventy eight SpA patients from the REGISPONSER registry were analysed in an observational study, which were evaluated for the first time in the year 2004-2005. The last x-rays analysis of the cervical and lumbar spine, pelvis and hips were recorded. Two independent observers evaluated the radiographs and calculated the BASRI index. The interobserver concordance was studied using Cohen's Kappa statistic. Finally, radiographic progression was assessed using the McNemar test.

Results: Sixty one SpA patients were radiographicaly evaluated at baseline and after 11 (1.7) years of follow-up. A complete radiographic study was recorded in 38 of them. The baseline characteristics, including BASRI values, as well as the treatment received are listed in table 1 . The strength of the interobserver concordance in the radiographic analysis was considerable in hips $(k=0.77, p<0.001)$ and almost perfect at the levels of the cervical spine $(k=0.88, p<0.001)$, lumbar spine $(\mathrm{k}=0.87, \mathrm{p}<0.001)$ and sacroiliac joints $(\mathrm{k}=0.84, \mathrm{p}<0.001)$. The BASRIs and BAS RIt scores were 7.5 (2.9) and 8.8 (4.1) respectively. Moreover, during the follow up, the BASRIt was increased in $1.23(\mathrm{p}=0.014)$. Individual analysis of the different components of BASRI, showed that $42.1 \%$ of SpA patients got worse regarding the score corresponding to the cervical spine $(p<0.001), 28.9 \%$ to the lumbar spine $(p=0.057), 15.8 \%$ to the hip $(p=0.754)$ and no worsening was found in sacroiliac $(p=0.500)$.

Abstract FRI0204 - Table 1. Baseline characteristics and current treatment of the cohort $\mathrm{N}=38$ for the radiographic study.

\begin{tabular}{|c|c|c|c|c|}
\hline $\begin{array}{l}\text { Type of SpA } \\
N(\%)\end{array}$ & $\begin{array}{l}\text { AS } 38 \\
(100 \%)\end{array}$ & $\begin{array}{c}\text { BASRIs } \\
\text { baseline } \\
\text { Mean (DS) } \\
\text { BASRIt } \\
\text { baseline } \\
\text { Mean (DS) }\end{array}$ & $\begin{array}{l}6.44(2.91) \\
7.60(3.96)\end{array}$ & $\begin{array}{c}\text { Current treatment } \\
\text { NSAIDs } \\
\text { N(\%) } \\
\text { Daily treatment: } 22 \\
(57.9 \%) \\
\text { Casual treatment: } 13 \\
(34.2 \%) \\
\text { Response: } 35(92.1 \%) \\
\text { Type: - } 18 \text { COX-2 } \\
\text { selective }(51.4 \%) \\
-7 \text { Diclofenac }(18.4 \%) \\
\text { - } 5 \text { Indomethacin } \\
(13.2 \%) \\
\text { - } 5 \text { Others }(13.2 \%)\end{array}$ \\
\hline $\begin{array}{l}\text { Time of evolution } \\
\text { Diagnosis-inclusion } \\
\text { in the registry } \\
\text { Mean (DS) years }\end{array}$ & $11(7.1)$ & $\begin{array}{c}\text { Degree of } \\
\text { sacroiliitis } \\
\mathrm{Me}(\mathrm{RI})\end{array}$ & $\begin{array}{c}4 \\
3^{3-4}\end{array}$ & $\begin{array}{c}\text { Current treatment } \\
\mathbf{N}(\%) \text { cDMARDs - } \\
\text { Sulfasalazine } 1(2.7 \%) \\
\text { - Methotrexate } 1(2.7 \%)\end{array}$ \\
\hline $\begin{array}{l}\text { Sex } \\
\text { Male } \\
\text { Female } \\
\mathrm{N}(\%)\end{array}$ & $\begin{array}{c}34 \\
(89.5) \\
4(10.5)\end{array}$ & $\begin{array}{l}\text { Degree of } \\
\text { cervical spine } \\
\text { Me }(R I)\end{array}$ & $\begin{array}{c}1 \\
(0-2)\end{array}$ & $\begin{array}{c}\text { Current treatment } \\
\text { N(\%) bDMARDs } \\
10(26.3 \%)-4 \\
\text { Golimumab }(10.5 \%) \\
\text { - } 3 \text { Etanercept }(7.9 \%) \\
\text { - } 1 \text { Adalimumab }(2.6 \%) \\
\text { - } 1 \text { Infliximab }(2.6 \%) \\
\text { - } 1 \text { Secukinumab } \\
(2.6 \%)\end{array}$ \\
\hline $\begin{array}{l}\text { Age } \\
\text { Mean (DS) years }\end{array}$ & $\begin{array}{l}58.2 \\
(7.9)\end{array}$ & $\begin{array}{c}\text { Degree of hips } \\
\text { Me (RI) }\end{array}$ & $\begin{array}{c}1 \\
(0-2)\end{array}$ & \\
\hline
\end{tabular}

Conclusions: This study provides information related to the structural progression of patients followed in a monographic consultation of SpA after 13 years of follow-up. Radiographic evolution was significantly noticed in relation to the tota score of the BASRI. However, analysing the individual scores it seems that the cervical spine was the segment where there was greater radiographic progres sion. We did not find worsening of BASRI in sacroiliac due to the fact that the most of patients already had an advanced degree of sacroileitis in the first visit of the registry.

Disclosure of Interest: None declared

DOI: 10.1136/annrheumdis-2018-eular.5637 